\title{
A meta-epidemiological study of subgroup analyses in cochrane systematic reviews of atrial fibrillation
}

\author{
Miney Paquette ${ }^{1,2^{*}}$ (D), Ahlam Mohammed Alotaibi ${ }^{3}$, Robby Nieuwlaat ${ }^{1}$, Nancy Santesso $^{1}$ and
} Lawrence Mbuagbaw ${ }^{1,4,5}$

\begin{abstract}
Background: Information on subgroup assessments in systematic reviews (SR) of atrial fibrillation (AF) is limited. This review aims to describe subgroup analyses in AF SRs to inform the design of SRs and randomized trials as well as clinical practice.

Methods: We conducted a cross sectional meta-epidemiological study of Cochrane AF reviews by searching AF (including variants) in the title, abstract, or keyword field without date or language restrictions (Issue 9; September 2018). Two reviewers independently extracted study characteristics to summarize frequency of subgroups prespecified and conducted and report credibility of subgroup effects claimed.
\end{abstract}

Results: Of 39 Cochrane reviews identified, 17 met inclusion criteria (including 168 reports of 127 randomized trials) and the majority $(16 ; 94.1 \%)$ conducted meta-analysis of outcomes. Most $(13 ; 76.5 \%)$ planned pre-specified subgroup analyses; 7 of which (41.2\%) conducted subgroups. In these 7 reviews, 56 subgroups were planned, 17 (30.4\%) conducted and 6 (10.7\%) yielded subgroup effects. Variables such as co-morbid disease, stroke risk factors, prior stroke/transient ischemic attack, age, race, and sex represented 44\% (24 subgroups) of all planned subgroups (8 conducted; 14.3\%); however, information on covariate selection was lacking. Overall, more subgroups were planned than conducted (mean difference (95\% Cl) $2.3(1.2-3.5, p<0.001))$. Of all subgroups conducted, anticoagulant characteristics comprised a third of all subgroup effects $(n=5,35.7 \%)$.

The credibility of subgroups identified $(n=14)$ was assessed and less than half $(43 \%)$ represented one of a small number of pre-specified hypothesis and rarely were effects seen within studies (7\%). Of 5 reviews that reported subgroup effects, only 3 discussed subgroup effects as part of the overall conclusions; none discussed credibility of subgroup effects.

Conclusions: This meta-epidemiological review of a subset of Cochrane AF reviews suggests that planning and reporting of subgroup analyses in AF reviews can be improved to better inform clinical management. Most pre-specified subgroup analyses were not performed, important variables (such as stroke, bleeding risk, and other comorbidities) were rarely examined and credibility of subgroup effects claimed was low. Future reviews should aim to identify important subgroups in their protocols and use recommended approaches to test subgroup effects in order to better support clinical decision-making.

Keywords: Meta-epidemiological review, Atrial fibrillation, Subgroup analyses

\footnotetext{
* Correspondence: miney.paquette@boehringer-ingelheim.com

${ }^{1}$ Department of Health Research Methods, Evidence, and Impact, McMaster University, Hamilton, Ontario L8S 4K1, Canada

${ }^{2}$ Medical Department, Boehringer Ingelheim Ltd., Burlington, Ontario, Canada

Full list of author information is available at the end of the article
}

(c) The Author(s). 2019 Open Access This article is distributed under the terms of the Creative Commons Attribution 4.0 International License (http://creativecommons.org/licenses/by/4.0/), which permits unrestricted use, distribution, and reproduction in any medium, provided you give appropriate credit to the original author(s) and the source, provide a link to the Creative Commons license, and indicate if changes were made. The Creative Commons Public Domain Dedication waiver (http://creativecommons.org/publicdomain/zero/1.0/) applies to the data made available in this article, unless otherwise stated. 


\section{Background}

Systematic reviews (SR) comprised of studies evaluating a central research question are considered to be the pinnacle of the medical evidence hierarchy [1]. To evaluate effects of interventions, combining studies and synthesizing results can provide greater confidence of treatment effects to draw conclusions than individual studies could provide in isolation [2]. Subgroup analyses may be conducted in SRs by dividing data across studies into groups based on participant or study characteristics in order to compare them or to partition out sources of heterogeneity from an overall effect, providing evidence to better guide clinical decision making compared to broad summaries of effects across diverse types of studies and participants $[2,3]$. The latter may not confidently inform about optimal treatments for individual or specific groups of patients [4]. Although subgroup analyses may be helpful to understand potential differences in patient or study characteristics, such investigations are uncommon because sufficient information is typically not available in published reports. Furthermore, interpretation should be made appreciating the risk for increasing probability of type 2 error concurrent with the number of subgroup analyses conducted [2].

Clinical heterogeneity is a term broadly used to include patient variability in clinical attributes as well as treatment variability that can include factors such as timing, formulation, doses, and duration, as well as variability in the settings in which treatments are delivered and measurement of outcomes [4]. Variability in study designs or quality of the studies is referred to as methodological heterogeneity, and together these sources of heterogeneity contribute to statistical heterogeneity, characterized by different magnitudes of treatment effect observed between studies in meta-analysis [4]. Consistency in effects support overall quality of evidence and tools for evaluating consistency include measures of heterogeneity such as $I$-squared $\left(I^{2}\right)$ [5], extent of overlap in confidence intervals and similar point estimates of effect [6]. Meta-regression is another method for assessing the relationship between one or more study level covariates and the effect size in studies which accommodates continuous, as well as categorical covariates and allows consideration of multiple covariates in the same model when there are adequate numbers of studies [7]. Several papers have been published, which emphasize the importance of evaluating and incorporating identified heterogeneity in the final interpretation of results $[3,4,8,9]$.

\section{Planning and interpretation of subgroup analyses}

Analyses of subgroups can help elucidate key sources of clinical heterogeneity; however, sufficient guidance on which important subgroups should be examined is lacking for specific disease areas. Generally, the most important subgroups to examine should be pre-specified based on presumed or known relationships to outcomes but standardized approaches to determining which subgroups to investigate do not exist. Broad recommendations for investigating clinical heterogeneity have been proposed such as ensuring that evaluations are prespecified, with clear rationale [4]. Furthermore, as there is risk for spurious subgroup effects, guidance has been published to help assess credibility of subgroup effects by evaluating 5 key criteria including the establishment of a limited number of important subgroups which are pre-specified according to some biological basis [10].

Previous meta-epidemiological reviews have identified other limitations of SRs such as suboptimal application of statistical testing principles with low proportions of reviews reporting appropriate interaction effect testing $[11,12]$ and minimal discussion of implications for possible confounding within subgroup analyses [11-13].

\section{Subgroup analyses in atrial fibrillation}

Systematic reviews of AF have not been explored to describe the extent to which subgroup analyses are prespecified and conducted, nor have important subgroups across AF reviews been reported. AF patients have diverse co-morbidities such as coronary artery disease, diabetes, heart failure, and hypertension, as well as variability in frequency and patterning of AF episodes and symptom burden [14]. In prospective studies, it has been demonstrated that advanced age, female sex and co-morbid diseases such as diabetes, heart failure, prior stroke, or transient ischemic attack are independent risk factors for stroke [15, 16]. Broader evaluation of additional sources of heterogeneity that may contribute to overall treatment differences could provide important insights to guide optimal management of this increasingly prevalent arrhythmia which is well recognized as an important independent risk factor for ischemic stroke [17].

Factors identified that increase stroke risk (for example, advanced age and co-morbid diseases such as impaired left ventricular systolic function) $[18,19]$ may be of particular interest in systematic reviews of AF. Other clinical factors such as bleeding risk may also be subgroups of interest due to their link to important outcomes [20]. How often these, or other important subgroup analyses, are planned and conducted in AF SRs and which subgroup effects are associated with important outcomes has not been systematically established. Furthermore, whether subgroup effects are included in the final conclusions has not been reported. Finally, the quality of reviews and whether quality is associated with subgroup analyses planned or conducted has not been examined.

As little is known about which subgroups are most important to explore in AF SRs or if there are any potential inherent limitations to subgroup analyses reported in SRs in $\mathrm{AF}$, a meta-epidemiological review was undertaken. The 
purpose of this review is to describe subgroup analyses in AF SRs in order to inform the design of systematic reviews and randomized trials as well as clinical practice.

The objectives of this methodological review are to describe subgroup analyses including:

- How often and which subgroup analyses are prespecified;

- Report subgroup analyses conducted (pre-specified as well as conducted post-hoc);

- Summarize the most frequently identified subgroup effects;

- Assess whether subgroup effects are included in conclusions; and

- Assess credibility of subgroup effects identified [10].

In addition, the quality of reviews using AMSTAR-2 (A MeaSurement Tool to Assess systematic Reviews) criteria [21] will be assessed to determine if subgroups planned or conducted differ with respect to the quality of reviews.

\section{Methods}

We conducted a cross-sectional, meta-epidemiological review from the Cochrane library (Issue 9; September 2018) extracting information from the eligible systematic reviews. We focused this review only on Cochrane reviews because of their methodological and reporting consistency. There were no sample size calculations as we included all the eligible studies in our sampling frame. Reporting of this review was conducted in general consideration of published recommendations and guidelines for reporting meta-epidemiological methodology research [22] (see Additional file 1 for additional details). A protocol was not registered for this review.

Subgroup analyses were considered pre-specified if covariates were included in a registered protocol for the review or if it was explicitly stated in the review that it was pre-specified prior to data collection. Post hoc analyses were defined as analyses which were not included as planned subgroups in protocols and for which there was no mention of pre-specification in the SR report or if they were explicitly identified as post hoc evaluations.

\section{Search}

We searched the Cochrane Database of Systematic Reviews for reviews current to 5 Sept. 2018 (https://www. cochranelibrary.com/advanced-search) using "atrial fibrillation" in the title, abstract, or keyword fields without date, language, study type, or other filters ["atrial fibrillation:ti,ab,kw"; including word variants for atrial fibrillation]. The studies were independently screened by two authors. The selection of articles was conducted in duplicate with any discrepancies of included reviews to be reviewed and assessed by a third author. Separate searches of the Cochrane Library of registered protocols using the term "atrial fibrillation" (including variants and without any "date", "status", "language", "type" or "topic" filters) and the International Prospective Register of Systematic Reviews at https://www.crd.york.ac.uk/PROSPERO/ (PROSPERO) [23] were conducted to retrieve protocols which were available as of the search date on 4 Nov. 2018. Authors were not contacted for confirmation of data or missing information.

\section{Eligibility criteria and selection}

Cochrane systematic reviews in AF patients were included irrespective of study design of included studies, or whether the category of review was interventional, prognostic, or diagnostic in nature. AF reviews which did not clearly identify AF patients (e.g., mixed indications for antithrombotic treatment without clear identification of the number of AF patients comprised in the group), or those that evaluated $\mathrm{AF}$ as an outcome (e.g., post-operative AF as an outcome) were excluded. As AF assessed postoperatively can represent a transient outcome with patients often returning to sinus rhythm, these SRs were determined to be outside of the scope of this review. Furthermore, as AF was our primary indication and patient group of interest, SRs that did not explicitly target or identify AF sub populations were excluded.

Cochrane reviews can be withdrawn when the question is no longer relevant or if the information is included in another review. As one of the main objectives was to evaluate methodology, we included withdrawn reviews. Where updates to reviews were conducted, the most current version of the review was included. The search results were independently screened by two researchers who were also trained to independently extract the data. The first researcher was trained by a senior researcher and the second researcher was trained by the first. Disagreement and discrepancies in results were discussed and resolved.

\section{Data collection and analysis}

We constructed data collection forms prior to performing the search, extracting key data from the reviews including the author information, year of publication, category of review (e.g. therapeutic/interventional, prevention), study design, primary objectives, number and types of studies included, total number of patients, indications, meta-analyses conducted or not, primary and secondary outcomes, deviations from protocols, number and type of subgroup analyses pre-specified and conducted, reasons for not conducting subgroup analyses, post hoc analyses conducted, and total number of subgroup effects identified (pre-specified and post hoc). Two authors piloted the data collection forms in 5 SRs 
and made minor revisions to facilitate extraction which was performed in duplicate by the same authors.

Data were summarized as frequency and percentage for categorical variables and means with standard deviations for continuous items. Where data were not normally distributed, median and interquartile ranges (IQR) were presented. Comparisons were quantified using mean differences with $95 \%$ confidence interval (CI), for number of pre-specified versus conducted analyses (with paired $t$ test used to assess significance). There were no further transformations of the data or imputation of any missing parameters. Data were summarized and analyzed in Microsoft Excel (2016).

The most important subgroups in each SR (pre-specified or post hoc) were identified by evaluating the magnitude of subgroup effects using odds ratios and 95\% CI. The most frequent subgroup effects identified across reviews were categorized and plotted for all SRs included.

Methodological quality of reviews was assessed using $A$ MeaSurement Tool to Assess Systematic Reviews (AMSTAR-2) [21] by 2 independent reviewers. In accordance with AMSTAR-2, we rated the overall quality assessment of the review as high if there were no critical weaknesses in the review, moderate if there was more than one non-critical weakness but no critical flaw, low if there was one critical weakness (with or without non-critical weakness) or critically low if there was more than one critical flaw with or without non-critical weakness [21].

Reviews assessed as high quality were compared to those of moderate, low, or critically low quality in number of pre-specified subgroup analyses planned and conducted, overall number of subgroup analyses conducted and number of subgroup effects identified. Two-sample, unequal variance $t$ tests were conducted to assess if there were any statistically significant differences between highand moderate-/low-/critically low- quality reviews.

For subgroup effects identified, the credibility of each effect was assessed by one reviewer using the criteria outlined by Sun et al. including whether results could have been due to chance, consistency of subgroups across studies, whether a limited number of important subgroups according to some biological basis were prespecified, and whether evidence came from within or between study comparisons [10].

\section{Results}

\section{Systematic review characteristics}

We identified a total of 39 systematic reviews and 18 records were excluded following title and abstract review (11 were not in an AF population and 7 assessed AF as an outcome). An additional 4 SRs were excluded based on full-text review as they were not exclusively in an AF population and AF patients could not be clearly differentiated from the total patient population (Fig. 1).

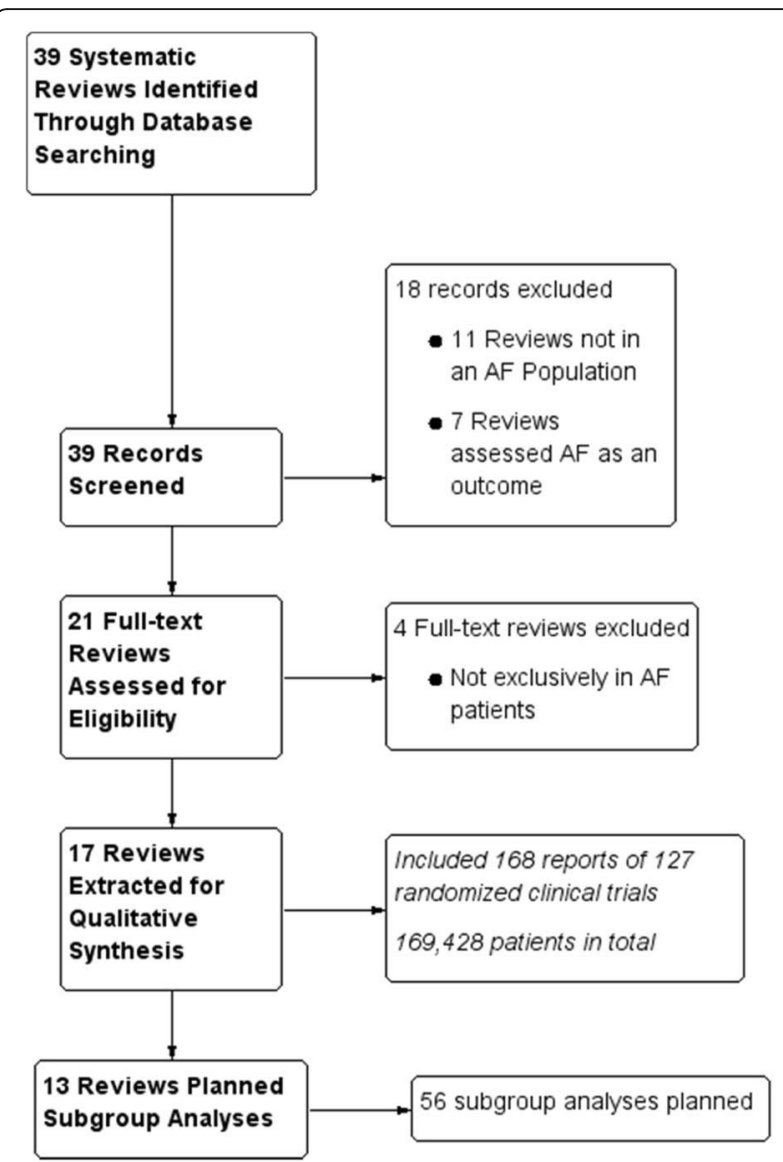

Fig. 1 Systematic reviews

A total of 17 SRs [24-40] which were published between 2004 and 2018 met final eligibility for qualitative and quantitative assessment (Fig. 1). Half of the SRs investigated oral anticoagulants or antiplatelets for stroke prevention $(n=9$, $52.9 \%)$ [24-29, 31, 35, 38]; 4 evaluated surgery, cardioversion, or ablation $(23.5 \%)$ [33, 37, 40, 41]; 2 evaluated behavioral interventions (11.8\%) [30, 36]; 1 (5.9\%) was an $\mathrm{AF}$ detection review [39]; and 1 (5.9\%) evaluated antiarrhythmic medications [34]. The median number of primary outcomes was 2 (IQR 2) and secondary outcomes was 5 (IQR 5). Detailed SR characteristics are presented in the Appendix. One of the SRs was subsequently noted as withdrawn but the report was published and results were available; therefore, information was extracted and included in the quantitative and qualitative assessment [40].

\section{Subgroup analyses}

\section{Pre-specified subgroup analyses}

All but one [39] of the reviews $(n=16 ; 94.1 \%)$ conducted meta-analysis of outcomes. The majority of reviews planned to explore heterogeneity with pre-specified subgroup analyses in 13 of the 17 reviews (76.5\%; Table 1 ) [26, 29-40]. In subsequent evaluation of the protocols 
Table 1 Systematic review characteristics

\begin{tabular}{|c|c|}
\hline & $\begin{array}{l}\text { Total reviews } \\
(N=17)\end{array}$ \\
\hline Reviews with meta-analysis*: $n(\%)$ & $16(94.1 \%)$ \\
\hline \multicolumn{2}{|l|}{ Pre-specified subgroups } \\
\hline Reviews with pre-specified subgroups ${ }^{a}$ & $13(76.5 \%)$ \\
\hline Planned covariates for subgroup analysis: median (min, max) & $3(0,6)$ \\
\hline Reviews with subgroup analyses conducted: $n(\%)^{b}$ & $7(41.2 \%)$ \\
\hline Covariates used in subgroup analyses: median (min, max) & $2(1,6)$ \\
\hline Reviews with subgroup effects ${ }^{* *}: n(\%)^{c}$ & $3(17.6 \%)$ \\
\hline Covariates in subgroup analyses: median (min, max) & $2(1,3)$ \\
\hline \multicolumn{2}{|l|}{ Post hoc subgroup analyses } \\
\hline Reviews with post hoc subgroup analyses ${ }^{d}$ & $5(29.4 \%)$ \\
\hline Reviews with post hoc subgroup effects: $n(\%)^{\mathrm{e}}$ & $4(23.5 \%)$ \\
\hline Covariates used in subgroup analyses: median (min, max) & $1(1,5)$ \\
\hline \multicolumn{2}{|l|}{ Any subgroup analyses performed, pre-specified, or Post Hoc } \\
\hline Reviews with any subgroup analyses $^{f}$ & $9(52.9 \%)$ \\
\hline Covariates used in subgroup analyses: median (min, max) & $2(1,11)$ \\
\hline Number with subgroup effects: $n(\%)$ & $5(29.4 \%)$ \\
\hline \multicolumn{2}{|l|}{ No subgroup analyses performed } \\
\hline Reviews with no subgroup analyses performed ${ }^{g}$ & $8(47.1 \%)$ \\
\hline \multicolumn{2}{|l|}{ Reasons for not conducting subgroup analyses: $n(\%)$} \\
\hline Insufficient data/studies & $4(23.5 \%)$ \\
\hline Not planned & $4(23.5 \%)$ \\
\hline
\end{tabular}

*One review [39] did not conduct meta-analysis due to insufficient studies

a[26, 29-40]

$\mathrm{b}[29,30,33,35,36,38,39]$

c[35, 38, 39]

$\mathrm{d}[24,30,31,35,38]$

$\mathrm{e}[30,31,35,38]$

$\mathrm{f}[24,29-31,33,35,36,38,39]$

g[25-28, 32, 34, 37, 40]

**Sub-group effects were characterized by $p \leq 0.05$ for interaction terms, using $\mathrm{Chi}^{2}$ test for subgroup differences. This does not include 3 reviews which presented effects within a subgroup but did not test for interaction effects.

and reviews, details were not provided on how prespecified covariates were selected (or if they comprised a subset of a larger group of pre-specified covariates initially under consideration) and potential for confounding and how it would be managed was not addressed.

In these 13 reviews, there were 56 subgroup analyses planned with the most common subgroups being comorbid disease (chronic kidney disease, diabetes, heart failure/impaired left ventricular dysfunction, 12.5\%); anticoagulant type, dose, or quality (12.5\%); type of AF (paroxysmal and persistent, 10.7\%); age (10.7\%); stroke risk scores (8.9\%); and sex (8.9\%). Co-morbid disease, stroke risk factors, prior stroke/transient ischemic attack (TIA), age, and sex are important subgroups based on their established relationships to outcomes [18-20], yet they represented only $42.8 \%$ (24 subgroups) of all planned subgroup analyses of which $14.3 \%$ were conducted (8 subgroups).
Of the 13 reviews that planned to conduct a total of 56 pre-specified analyses, 7 reviews [3, 29, 30, 35, 36, 38, 39] conducted a total of 17 (30.4\%) subgroup analyses, of which 3 reviews $(17.6 \%)[35,38,39]$ yielded a total of 6 subgroup effects (Table 2). The mean difference (95\% CI) between the number of planned and conducted subgroup analyses per SR was $2.3(1.2-3.5, p<0.001)$, and the reasons for not conducting subgroup analyses $(n=39)$ were insufficient studies or lack of data (92.7\%) or were not further explained (7.3\%). Many of the important planned subgroup analyses such as stroke risk, sex, age, or comorbidities, such as heart failure or diabetes, were not conducted (Fig. 2).

For reviews that did not conduct subgroup analyses, the median (IQR) of included studies and patients was 3.0 (4.5) and 1149.0 (1894.8) respectively, compared to a median of 11.0 (17.0) studies and $9137.0(18,992.0)$ patients in reviews that conducted subgroup analyses $(\mathrm{p}=$ 
Table 2 Subgroup characteristics

\begin{tabular}{|c|c|}
\hline \multicolumn{2}{|l|}{ Total subgroup analyses planned or conducted $(n=66)$} \\
\hline Pre-specified subgroup analyses & 56 \\
\hline Pre-specified subgroup analyses conducted (\% of planned) & $17(30.4 \%)$ \\
\hline Subgroup effects reported (\% of pre-specified conducted) & $6(35.3 \%)$ \\
\hline Stroke risk $(n)^{\mathrm{a}}$ & $1(1.8 \%)$ \\
\hline Age $(n)^{b}$ & $1(1.8 \%)$ \\
\hline $\operatorname{Sex}(n)^{c}$ & $1(1.8 \%)$ \\
\hline Country/race $(n)^{d}$ & $1(1.8 \%)$ \\
\hline Indication $(n)^{\mathrm{e}}$ & $1(1.8 \%)$ \\
\hline Anticoagulation self-management $(n)^{f}$ & $1(1.8 \%)$ \\
\hline Post hoc subgroup analyses conducted & 10 \\
\hline Subgroup effects reported (\% of post hoc conducted) & $8(80 \%)$ \\
\hline Anticoagulation: dose, route, type, or quality $(n)^{g}$ & $5(50.0 \%)$ \\
\hline Type of antiarrhythmic $(n)^{\mathrm{h}}$ & $1(10.0 \%)$ \\
\hline Older and newer quinidine studies $(n)^{\mathrm{i}}$ & $1(10.0 \%)$ \\
\hline Concomitant antiplatelet use $(n)^{j}$ & $1(10.0 \%)$ \\
\hline Total pre-specified or post hoc subgroup analyses conducted & 27 \\
\hline Subgroup effects reported (\% of all conducted) & $14(51.9 \%)$ \\
\hline $\begin{array}{l}a[35] \\
b[35] \\
c[39] \\
d[35] \\
e[38] \\
f[38] \\
g[31,35,38] \\
h[30] \\
i[35]\end{array}$ & \\
\hline
\end{tabular}

0.05 , and $\mathrm{p}=0.01$ respectively for comparisons by Mann-Whitney U test).

\section{Post hoc subgroup analyses}

A total of 10 post hoc subgroup analyses were conducted in 5 reviews $(29.4 \%)$ [24, 30, 31, 35, 38]; the majority of these comparisons (80\%) showed subgroup effects. These included anticoagulant characteristics (including type, dose, quality, or route, $n=5$ ), antiarrhythmic drug class $(n=1)$, older and newer quinidine studies $(n=1)$, and concomitant antiplatelet use $(n=1)$.

\section{Subgroup effects identified All conducted subgroup analyses}

In 9 reviews [24, 29-31, 33, 35, 36, 38, 39], a total of 27 pre-specified or post hoc analyses were conducted, of which half yielded subgroup effects $(n=14 ; 51.9 \%)$. Subgroup effects were characterized by $p \leq 0.05$ for the interaction term using $\mathrm{Chi}^{2}$ test for subgroup differences. There were 3 reviews which presented effects within a subgroup but did not test for interaction effects $[29,30,33]$. The subgroup effects are further described in Table 2. The most frequent subgroup effect was related to characteristics of anticoagulation (including dose, quality, route, or type), comprising 5 subgroups representing $35.7 \%$ of all subgroup effects. The subgroup analyses planned and conducted and subgroup effects reported are shown in Fig. 2.

Studies with subgroup effects related to anticoagulation examined outcomes of stroke and bleeding. For example, in a review conducted by Bruins et al. [35]

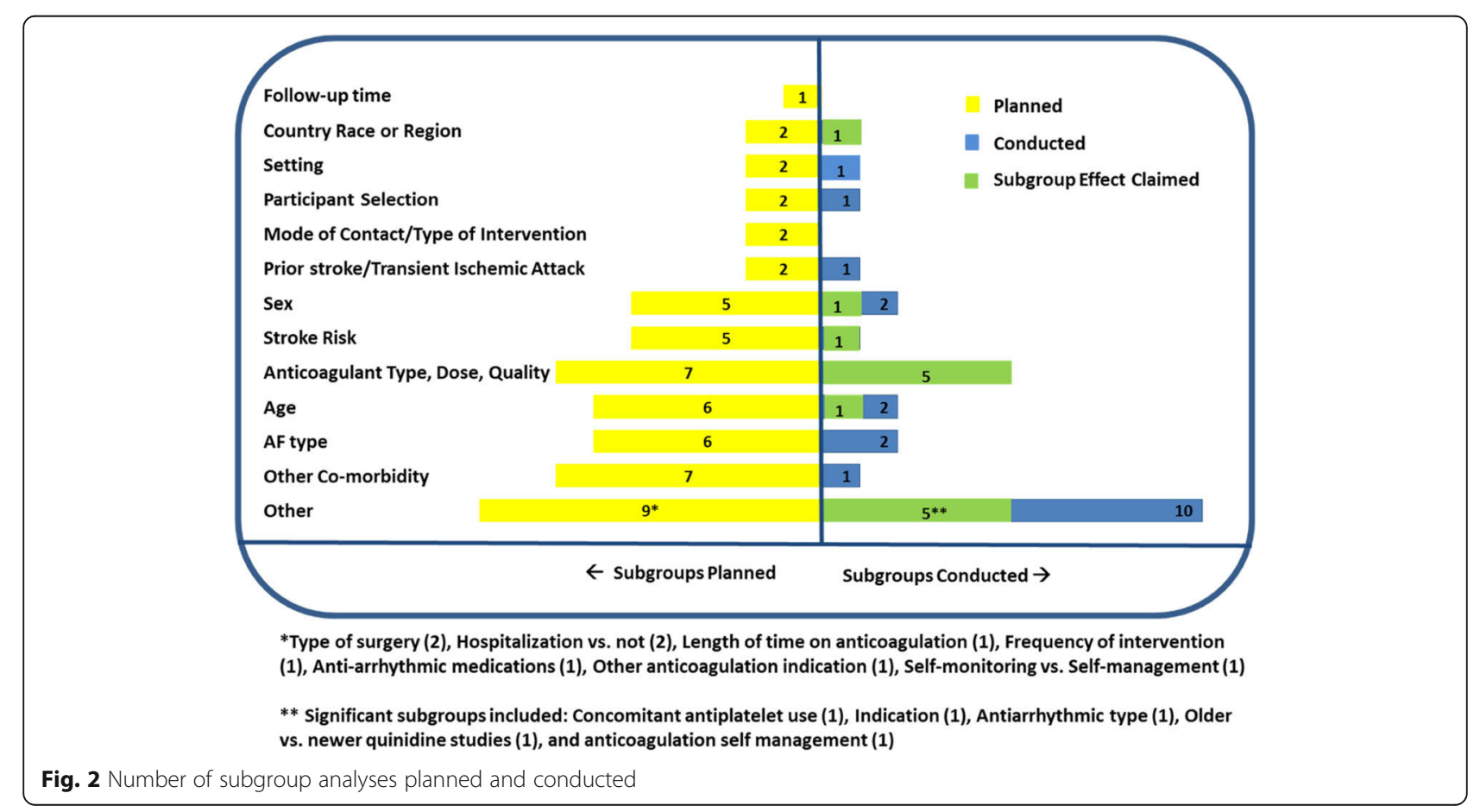


exploring Factor Xa inhibitors, there were differences in effect size estimates for patient important outcomes such as major bleeding events depending on the type of Factor Xa inhibitor given. The odds ratios for major bleeding compared to vitamin $\mathrm{K}$ antagonists (VKA) for some anticoagulants such as apixaban (odds ratio (OR), 95\% CI $0.69(0.60,0.80))$ and betrixaban (OR 0.19, 95\% CI $0.05,0.82)$ demonstrated a significant risk reduction compared to VKA. In contrast, idraparinux showed increased risk (OR 2.62, 95\% CI 1.70, 4.03) compared to VKA. The subgroup interaction effect was significant $\left(\mathrm{Chi}^{2}=63.01, p<0.01\right)$ with $I^{2}=90 \%$ indicating a high degree of heterogeneity attributable to type of Factor Xa inhibitor. In this review, dose and quality of anticoagulation (based on median time-in-therapeutic range $\leq 60 \%$ ("low/bad") versus $>60 \%$ ("high/good") quality treatment) as well as the route of administration showed evidence of heterogeneity in effect. Furthermore, the effect size for the outcomes of stroke and systemic embolic events were highly variable as a function of dose even within the same compound class.

The subgroup of older patients ( $\geq 75$ years) showed greater risk reduction than younger patients $(<75$ years) for stroke/systemic embolic events with Factor Xa inhibitors compared to VKA [35] (OR 0.76, 95\% CI 0.66, 0.88 and OR 0.96, 95\% CI 0.84, 1.09 for older and younger patients, respectively) with subgroup interaction effects $\left(\mathrm{Chi}^{2}=5.07, p=0.02\right)$, and high heterogeneity $\left(I^{2}=80 \%\right)$. Other subgroup effects identified included race (Asian, White, Black, and other) [35], as well as $\mathrm{CHADS}_{2}$ stroke risk score [42] (comprised of congestive heart failure, hypertension, age $\geq 75$ years, diabetes mellitus, and prior stroke/TIA, or thromboembolism) [35], sex [39], and patient self-management of anticoagulation [38]

\section{Quality of reviews}

\section{AMSTAR-2 quality of reviews}

The methodological quality of reviews was assessed as high in 8 reviews (47.1\%) [29, 31, 32, 34, 36-39] and low in 9 reviews $(52.9 \%)$ [24-28, 30, 33, 35, 40]. The main reason for SRs being assessed as low quality was due to incomplete assessment of risk of bias domains, and/or failure to discuss risk of bias in conclusions where bias was identified. Most SRs assessed as being of low quality only assessed the allocation concealment aspect of risk of bias and did not assess other domains such as random sequence generation, blinding of participants or personnel, blinding of outcome assessment, incomplete outcome data, or other types of bias [43]. Many SRs also did not meet criteria for a comprehensive search strategy as they failed to look at other sources such as gray literature or consultation with experts. The risk of bias assessment for the included reviews is presented in Additional file 2: AMSTAR-2 Risk of Bias for Included Systematic Reviews.
When comparing the quality of SRs between more recent reviews (2016 to Sept 2018) and earlier reviews (prior to 2016), there was a higher proportion of recent reviews that were considered of high quality (75.0\%), compared to earlier reviews $(22.2 \%)\left(\mathrm{Chi}^{2}=4.74, \mathrm{df}=1\right.$, $p=0.03)$. In addition, there was a higher average number of planned subgroup analyses in the high quality reviews compared to low quality reviews (mean (SD), 4.75 (1.58) and $2.00(2.45)$, respectively, $p=0.01$ ), but there were no significant differences in the overall number of subgroup analyses conducted (pre-specified or post hoc) or number of subgroups identified (Table 3).

\section{Credibility of subgroup analyses}

The credibility of subgroup effects was assessed for the 14 subgroup effects identified, with the most credible subgroup effects being stroke risk score by $\mathrm{CHADs}_{2}$ [35], sex [39], and age [35] of patients (these met 4 out of 5 subgroup credibility criteria) and many were moderately credible (meeting 3 credibility criteria), including oral anticoagulation type [35], dose [35], and race of patient [35]. The composite ratings for credibility of each of the subgroup effects are presented in Fig. 3 and the proportion of subgroup effects meeting each of the credibility criteria are presented in Fig. 4. Less than half of the subgroup effects met the criteria of being one of a small number of pre-specified hypotheses with direction of effect pre-specified (43\%), and few subgroup effects (7\%) were identified from data within studies. Furthermore, only half $(50 \%)$ of the subgroup effects were consistent across studies.

Of the 5 reviews that reported subgroup effects, 3 reviews [30, 35, 39] discussed and noted the subgroup effects as part of the overall conclusions and two reviews did not $[31,38]$. None of the reviews discussed credibility of subgroup effects in the discussion or conclusions.

\section{Discussion}

This methodological review highlights important gaps in Cochrane systematic reviews of AF. Although numerous subgroup analyses were planned, many could not be conducted due to insufficient studies including important subgroups such as those based on stroke and bleeding risk factors and important co-morbid conditions such as heart failure and diabetes. Similar findings have been reported in Cochrane SRs of HIV, showing that subgroup analyses are often not possible to conduct and subgroup effects are rare [44]. In addition, no reviews included details on how covariates were selected, or if statistical considerations necessitated an abbreviated list of covariates from an initial set pre-specified for investigation. We also found limitations in the quality of the reviews and the credibility of the subgroup effects were not discussed. In an earlier review, it was noted that 
Table 3 Subgroup differences and quality of reviews

\begin{tabular}{|c|c|c|c|c|c|c|}
\hline \multirow[t]{3}{*}{ Quality } & \multicolumn{6}{|c|}{ Subgroup analyses } \\
\hline & \multicolumn{3}{|l|}{ Planned } & \multicolumn{2}{|l|}{ Post hoc } & \multirow{2}{*}{$\begin{array}{l}\text { Planned or post hoc } \\
\text { Subgroup effects }\end{array}$} \\
\hline & Planned & Conducted & Subgroup effects & Conducted & Subgroup effects & \\
\hline Low: mean (SD) & $2.00(2.45)$ & $1.11(2.09)$ & $1.50(2.12)$ & $0.33(0.50)$ & $1.75(2.36)$ & $3.25(4.48)$ \\
\hline High: mean (SD) & $4.75(1.58)$ & $0.88(0.99)$ & $0.75(0.96)$ & $0.25(0.46)$ & $0.29(0.49)$ & $0.63(1.06)$ \\
\hline$p$ value (T-test) & 0.02 & 1.00 & 0.71 & 0.62 & 0.30 & 0.57 \\
\hline
\end{tabular}

$S D$ standard deviation

most Cochrane review authors did not adequately interpret or report subgroup analyses, nor did the review authors discuss the plausibility of effects [12]. Although only observed in a relatively small number of Cochrane reviews, these issues may potentially extend to other reviews in this area and should be further explored (in both primary studies and reviews, including metaepidemiological reviews).

Guidance for systematic planning of investigations of heterogeneity have been provided, with recommendations to outline these a priori in a protocol, providing a clear rationale with appropriate consideration of the multiple sources and levels of possible heterogeneity, guided by clinical expert opinion [4]. This review has identified gaps in planning and conduct of AF SRs in a subset of Cochrane SRs. Of the subgroup analyses conducted, only half revealed subgroup effects and most of these were not pre-specified which raises the suspicion of selective post hoc reporting. As subgroups identified from a limited number of pre-specified hypotheses have greater credibility than those conducted post hoc, this may be an important methodological consideration for future systematic reviews and primary studies. Further important limitations to the subgroup effects identified in these reviews are that most effects were identified between studies rather than within studies and only half of the subgroup effects identified were consistent across studies. There are resources available for SR review authors which can be consulted prior to planning of SRs which may improve interpretation of subgroup analyses $[2,12,45]$. Important topics related to investigation of subgroups in SRs such as issues of confounding, and the inherent observational nature of these analyses should be addressed in the interpretation of any findings [2], issues which may also extend to randomized trials that are included in the reviews [46]. Without these appropriate considerations, the subgroup effects claimed may be misleading.

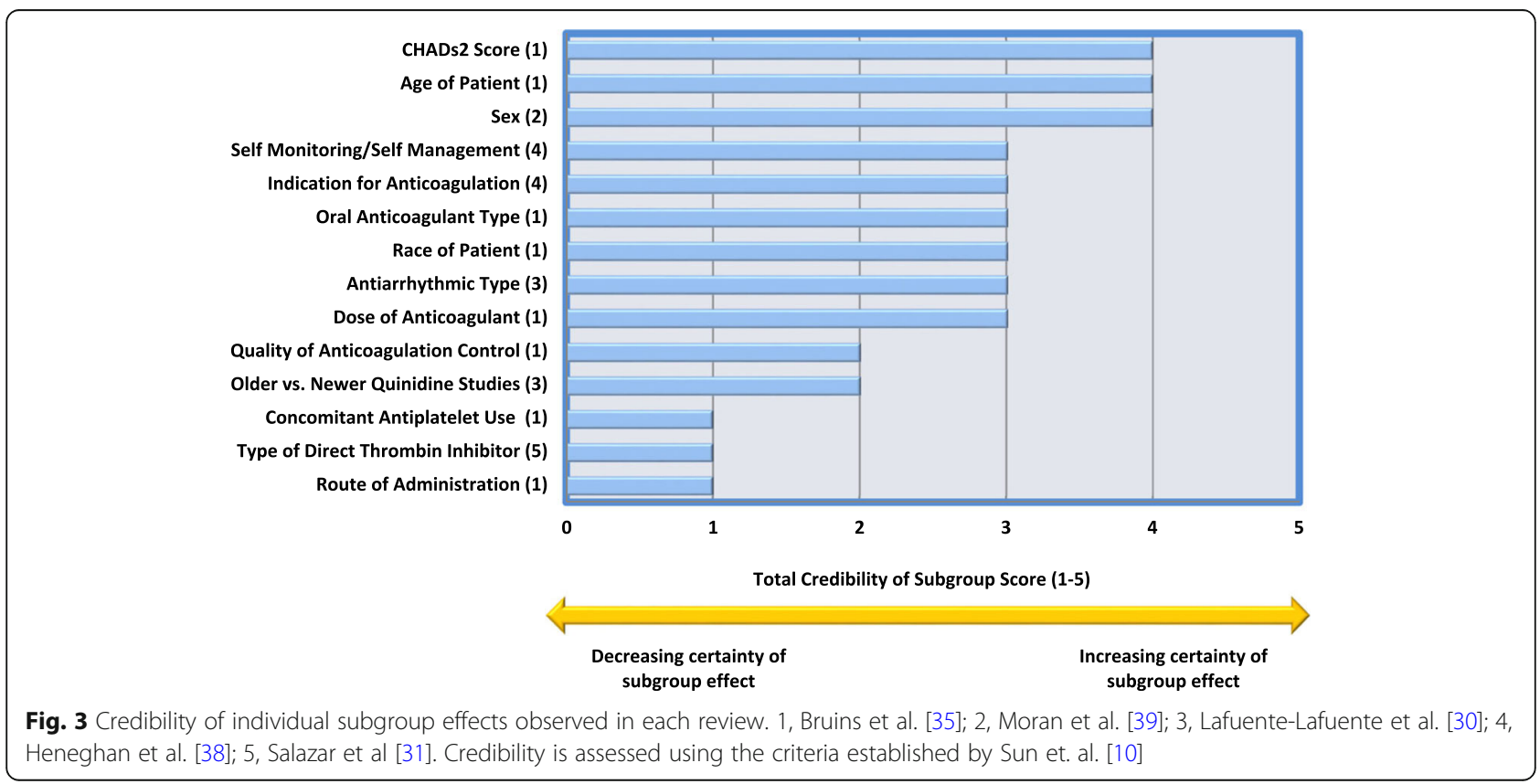




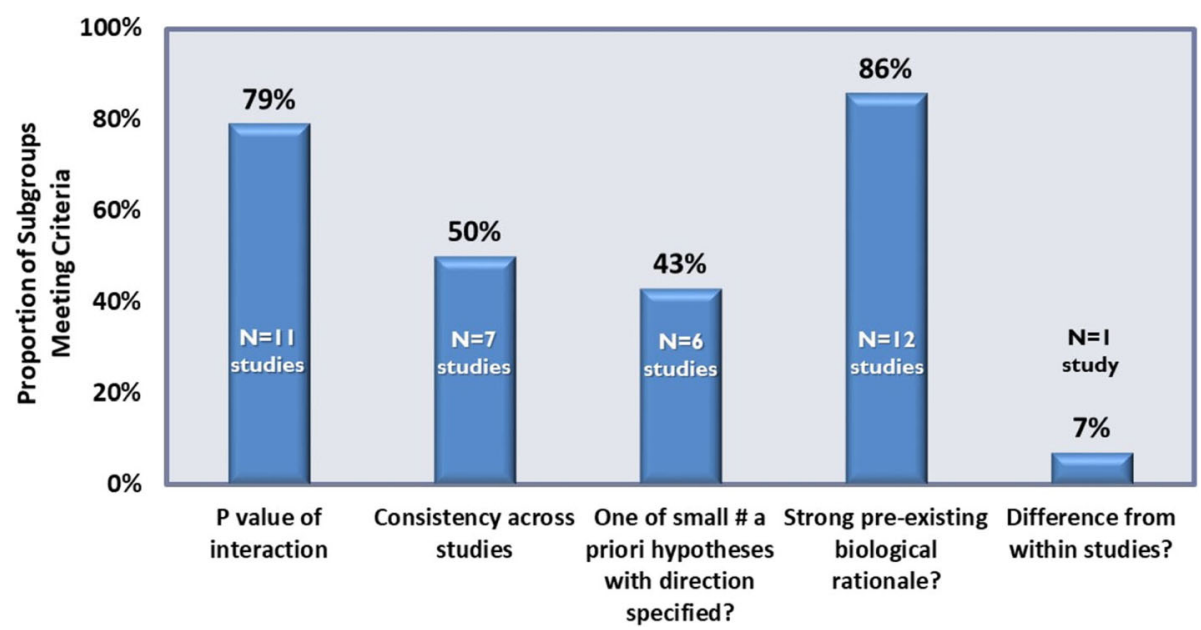

Fig. 4 Overall credibility measures of subgroup effects. Credibility is assessed using the criteria established by Sun et. al. [10]

Although more than half of the reviews were assessed as low quality, there was some evidence that this was driven by our improved understanding and updating of important risk of bias domains assessed in systematic reviews [47] as more recent SRs were more often rated as being of high quality. Of note, the high quality reviews planned more subgroup analyses on average than low quality reviews.

\section{Subgroup effects identified}

This review showed that anticoagulant characteristics including type, route, quality, and dose, although rarely pre-specified for subgroup analysis, may have important differences in treatment effect which should be more broadly evaluated. As head to head comparisons of some treatments such as comparisons within the classes of non-VKA oral anticoagulants (NOAC) are rarely available in clinical trials, systematic reviews could help guide clinical decision-making if credible subgroup analyses show differences in outcomes between anticoagulant types or show that some patient subgroups fare better with one type of NOAC compared to another.

The relatively small number of investigated covariates related to co-morbidities, stroke risk, and AF type suggest that there may be a lack of sufficient data in the primary studies to make these comparisons. It is therefore important to encourage researchers to report data on important subgroups in the primary studies so these can also be more robustly evaluated in systematic reviews.

\section{Limitations}

This meta-epidemiological review of SRs of AF exclusively evaluated Cochrane reviews which represents approximately $15 \%$ of SRs conducted [48] and limits the generalizability of findings. Although different subgroups may be identified in journal articles or health technology assessments, the methodological issues identified are likely underestimated if extended to other sources where established protocols for inquiry and reporting are absent. Furthermore, as subgroup analyses are limited to large-scale randomized trials, potentially important data from smaller or single-center studies may have been excluded. Including SRs published in other journals may provide more comprehensive insight into important subgroups which should be examined. The more recent availability of additional NOACs may warrant further evaluation as data becomes increasingly available, compelling publication of additional SRs and potentially a follow-up meta-epidemiological review.

\section{Conclusion}

This meta-epidemiological review of a subset of Cochrane AF reviews suggests that planning and reporting of subgroup analyses in AF reviews can be improved to better inform clinical management. Most prespecified subgroup analyses in AF SRs were not performed due to insufficient data, and important variables, such as stroke and bleeding risk, and comorbidities were rarely examined. Furthermore, the credibility of subgroups was not assessed or reported in the SRs. These results suggest that more comprehensive planning and reporting of subgroup analyses in Cochrane AF SRs is warranted to ensure the most clinically important subgroups are appropriately identified and interpreted and where possible, important heterogeneity is explained.

Future reviews should aim to identify important subgroups in their protocols and discuss credibility of subgroups effects to better support clinical decision-making. 


\section{Appendix}

\section{Table of systematic reviews}

\begin{tabular}{|c|c|c|c|c|c|c|c|c|}
\hline $\begin{array}{l}\text { Author } \\
\text { (year) }\end{array}$ & Title & Objectives & Studies included & $\begin{array}{l}\text { Trials } \\
(n)\end{array}$ & $\begin{array}{l}\text { Patients } \\
(n)\end{array}$ & Primary outcomes & $\begin{array}{l}\text { Types of } \\
\text { participants }\end{array}$ & $\begin{array}{l}\text { Types of } \\
\text { interventions }\end{array}$ \\
\hline $\begin{array}{l}\text { Huffman } \\
\text { et al. [33] }\end{array}$ & $\begin{array}{l}\text { Concomitant } \\
\text { atrial fibrillation } \\
\text { surgery for } \\
\text { people } \\
\text { undergoing } \\
\text { cardiac surgery }\end{array}$ & $\begin{array}{l}\text { To assess the } \\
\text { effects of } \\
\text { concomitant AF } \\
\text { surgery among } \\
\text { people with AF } \\
\text { who are } \\
\text { undergoing } \\
\text { cardiac surgery. }\end{array}$ & $\begin{array}{l}\text { RCTs evaluating } \\
\text { the effect of any } \\
\text { concomitant AF } \\
\text { surgery compared } \\
\text { with no AF } \\
\text { surgery }\end{array}$ & 22 & 1899 & $\begin{array}{l}\text { All-cause } \\
\text { mortality, } \\
\text { freedom from AF, } \\
\text { flutter, or } \\
\text { tachycardia. } \\
\text { Procedural safety } \\
\text { (adverse events) }\end{array}$ & $\begin{array}{l}\text { Adults with pre- } \\
\text { operative AF, } \\
\text { undergoing } \\
\text { cardiac surgery } \\
\text { for another } \\
\text { indication }\end{array}$ & $\begin{array}{l}\text { Any concomitant } \\
\text { AF surgery }\end{array}$ \\
\hline $\begin{array}{l}\text { Aguilar } \\
\text { et al. [26] }\end{array}$ & $\begin{array}{l}\text { Oral } \\
\text { anticoagulants } \\
\text { versus } \\
\text { antiplatelet } \\
\text { therapy for } \\
\text { preventing stroke } \\
\text { in patients with } \\
\text { non-valvular AF } \\
\text { and no history of } \\
\text { stroke or TIA }\end{array}$ & $\begin{array}{l}\text { To characterize } \\
\text { relative effect } \\
\text { of long-term OAC } \\
\text { treatment } \\
\text { compared with } \\
\text { antiplatelet } \\
\text { therapy on major } \\
\text { vascular events in } \\
\text { patients with } \\
\text { non-valvular AF } \\
\text { and no history } \\
\text { of stroke/TIA. }\end{array}$ & $\begin{array}{l}\text { RCTs in which } \\
\text { long-term } \\
\text { adjusted-dose } \\
\text { OAC was } \\
\text { compared with } \\
\text { antiplatelet } \\
\text { therapy in } \\
\text { patients with } \\
\text { chronic non- } \\
\text { valvular AF. }\end{array}$ & 8 & 9598 & $\begin{array}{l}\text { All strokes } \\
\text { (ischemic and } \\
\text { hemorrhagic) }\end{array}$ & $\begin{array}{l}\text { Non-valvular AF } \\
\text { patients, most } \\
\text { without previous } \\
\text { stroke or TIA }\end{array}$ & $\begin{array}{l}\text { Oral } \\
\text { anticoagulation } \\
\text { by vitamin } \mathrm{K} \\
\text { antagonists }\end{array}$ \\
\hline $\begin{array}{l}\text { Aguilar and } \\
\text { Hart [24] }\end{array}$ & $\begin{array}{l}\text { Oral } \\
\text { anticoagulants } \\
\text { for preventing } \\
\text { stroke in patients } \\
\text { with non-valvular } \\
\text { AF and no } \\
\text { previous history } \\
\text { of stroke or TIA }\end{array}$ & $\begin{array}{l}\text { To characterize } \\
\text { the efficacy } \\
\text { and safety of } \\
\text { OAC for the } \\
\text { primary } \\
\text { prevention of } \\
\text { stroke in patients } \\
\text { with chronic AF. }\end{array}$ & $\begin{array}{l}\text { RCTs } \\
\text { comparing OACs } \\
\text { with control in } \\
\text { patients with } \\
\text { chronic non- } \\
\text { valvular atrial } \\
\text { fibrillation and no } \\
\text { history of TIA/ } \\
\text { stroke. }\end{array}$ & 5 & 2313 & $\begin{array}{l}\text { All strokes } \\
\text { (ischemic and } \\
\text { hemorrhagic) }\end{array}$ & $\begin{array}{l}\text { Non-valvular AF; } \\
\text { most without } \\
\text { previous stroke } \\
\text { or TIA }\end{array}$ & $\begin{array}{l}\text { Oral } \\
\text { anticoagulants for } \\
\text { preventing stroke } \\
\text { in patients with } \\
\text { non-valvular AF }\end{array}$ \\
\hline $\begin{array}{l}\text { Aguilar and } \\
\text { Hart [25] }\end{array}$ & $\begin{array}{l}\text { Antiplatelet } \\
\text { therapy for } \\
\text { preventing stroke } \\
\text { in patients with } \\
\text { non-valvular atrial } \\
\text { fibrillation and no } \\
\text { previous history } \\
\text { of stroke or TIA }\end{array}$ & $\begin{array}{l}\text { To characterize } \\
\text { the effect of long- } \\
\text { term antiplatelet } \\
\text { on major vascular } \\
\text { events in patients } \\
\text { with non-valvular } \\
\text { AF and no history } \\
\text { of stroke or TIA. }\end{array}$ & $\begin{array}{l}\text { RCTs in which } \\
\text { long-term } \\
\text { antiplatelet was } \\
\text { compared to } \\
\text { placebo/control } \\
\text { in patients with } \\
\text { chronic non- } \\
\text { valvular AF. }\end{array}$ & 3 & 1965 & $\begin{array}{l}\text { All strokes } \\
\text { (ischemic and } \\
\text { hemorrhagic) }\end{array}$ & $\begin{array}{l}\text { Non-valvular AF } \\
\text { without previous } \\
\text { stroke or TIA }\end{array}$ & $\begin{array}{l}\text { Aspirin or other } \\
\text { specific platelet } \\
\text { anti-aggregants } \\
\text { given in any dose, } \\
\text { formulation, } \\
\text { combination, or } \\
\text { frequency were } \\
\text { considered. }\end{array}$ \\
\hline $\begin{array}{l}\text { Saxena and } \\
\text { Koudstaal } \\
{[27]}\end{array}$ & $\begin{array}{l}\text { Anticoagulants } \\
\text { for preventing } \\
\text { stroke in patients } \\
\text { with non- } \\
\text { rheumatic atrial } \\
\text { fibrillation and a } \\
\text { history of stroke } \\
\text { or TIA }\end{array}$ & $\begin{array}{l}\text { To determine the } \\
\text { value of } \\
\text { anticoagulant } \\
\text { treatment for the } \\
\text { long-term } \\
\text { prevention of } \\
\text { recurrent vascular } \\
\text { events in patients } \\
\text { with non-rheumatic } \\
\text { AF and previous } \\
\text { TIA or minor } \\
\text { ischaemic stroke. }\end{array}$ & $\begin{array}{l}\text { RCTs - Open-label } \\
\text { oral } \\
\text { anticoagulants } \\
\text { versus control or } \\
\text { double-blind } \\
\text { anticoagulant } \\
\text { treatment versus } \\
\text { placebo. }\end{array}$ & 2 & 485 & $\begin{array}{l}\text { Composite event } \\
\text { of vascular death, } \\
\text { nonfatal stroke, } \\
\text { nonfatal Ml or } \\
\text { systematic } \\
\text { embolism. }\end{array}$ & $\begin{array}{l}\text { Patients with } \\
\text { non-rheumatic } \\
\text { AF and a } \\
\text { previous history } \\
\text { of TIA or minor } \\
\text { ischaemic stroke. } \\
\text { Only included } \\
\text { patients without } \\
\text { contraindications } \\
\text { to anticoagulants. }\end{array}$ & $\begin{array}{l}\text { Anticoagulation } \\
\text { (INR 2.5-4.0 in one } \\
\text { study). }\end{array}$ \\
\hline $\begin{array}{l}\text { Saxena and } \\
\text { Koudstaal } \\
{[28]}\end{array}$ & $\begin{array}{l}\text { Anticoagulants } \\
\text { versus } \\
\text { antiplatelet } \\
\text { therapy for } \\
\text { preventing stroke } \\
\text { in patients with } \\
\text { non-rheumatic } \\
\text { atrial fibrillation } \\
\text { and a history of } \\
\text { stroke or TIA. }\end{array}$ & $\begin{array}{l}\text { To compare the } \\
\text { value of } \\
\text { anticoagulant and } \\
\text { antiplatelet } \\
\text { therapy for the } \\
\text { long-term } \\
\text { prevention of } \\
\text { recurrent vascular } \\
\text { events in patients } \\
\text { with non-rheumatic AF. }\end{array}$ & $\begin{array}{l}\text { RCTs comparing } \\
\text { anticoagulants to } \\
\text { antiplatelets in } \\
\text { patients with } \\
\text { prior TIA or } \\
\text { stroke. }\end{array}$ & 2 & 1371 & $\begin{array}{l}\text { Composite event } \\
\text { of vascular death, } \\
\text { nonfatal stroke, } \\
\text { nonfatal } \\
\text { myocardial } \\
\text { infarction or } \\
\text { systematic } \\
\text { embolism. }\end{array}$ & $\begin{array}{l}\text { Patients with } \\
\text { non-rheumatic } \\
\text { AF and a } \\
\text { previous history } \\
\text { of TIA or minor } \\
\text { ischaemic stroke. } \\
\text { Excluded patients } \\
\text { with poorly } \\
\text { controlled } \\
\text { hypertension. }\end{array}$ & $\begin{array}{l}\text { Anticoagulation } \\
\text { (INR } 2.5-4.0 \text { in one } \\
\text { study; } 2.4-3.0 \text { in } \\
\text { the other). }\end{array}$ \\
\hline
\end{tabular}


(Continued)

\begin{tabular}{|c|c|c|c|c|c|c|c|c|}
\hline $\begin{array}{l}\text { Author } \\
\text { (year) }\end{array}$ & Title & Objectives & Studies included & $\begin{array}{l}\text { Trials } \\
(n)\end{array}$ & $\begin{array}{l}\text { Patients } \\
(n)\end{array}$ & Primary outcomes & $\begin{array}{l}\text { Types of } \\
\text { participants }\end{array}$ & $\begin{array}{l}\text { Types of } \\
\text { interventions }\end{array}$ \\
\hline $\begin{array}{l}\text { Kimachi } \\
\text { et al. [29] }\end{array}$ & $\begin{array}{l}\text { Direct OAC } \\
\text { versus warfarin } \\
\text { for preventing } \\
\text { stroke and } \\
\text { systemic embolic } \\
\text { events among } \\
\text { atrial fibrillation } \\
\text { patients with } \\
\text { chronic kidney } \\
\text { disease }\end{array}$ & $\begin{array}{l}\text { To assess the } \\
\text { efficacy and } \\
\text { safety of DOAC } \\
\text { including } \\
\text { apixaban, } \\
\text { dabigatran, } \\
\text { edoxaban, and } \\
\text { rivaroxaban } \\
\text { versus warfarin } \\
\text { among AF } \\
\text { patients with } \\
\text { CKD. }\end{array}$ & $\begin{array}{l}\text { RCTs and } \\
\text { quasi-RCTs (RCTs } \\
\text { in which } \\
\text { treatment } \\
\text { allocation was by } \\
\text { predictable } \\
\text { methods such as } \\
\text { date of birth) } \\
\text { comparing DOAC } \\
\text { with warfarin. }\end{array}$ & 5 & 12,545 & $\begin{array}{l}\text { Composite of all } \\
\text { strokes and } \\
\text { systemic embolic } \\
\text { events. Major } \\
\text { bleeding or } \\
\text { symptomatic } \\
\text { bleeding in a } \\
\text { critical area or } \\
\text { organ. }\end{array}$ & $\begin{array}{l}\text { Eligible } \\
\text { participants were } \\
\text { diagnosed with } \\
\text { non-valvular AF } \\
\text { and moderate } \\
\text { kidney } \\
\text { impairment, } \\
\text { defined as CrCl } \\
\text { or eGFR between } \\
15 \text { and } 60 \mathrm{~mL} / \\
\text { min. }\end{array}$ & $\begin{array}{l}\text { DTIs including } \\
\text { apixaban, } \\
\text { dabigatran, } \\
\text { edoxaban, and } \\
\text { rivaroxaban as } \\
\text { well as any other } \\
\text { intervention } \\
\text { classified as } \\
\text { DOAC. Warfarin } \\
\text { was to be dose- } \\
\text { adjusted using } \\
\text { INR. }\end{array}$ \\
\hline $\begin{array}{l}\text { Lafuente- } \\
\text { Lafuente } \\
\text { et al. [30] }\end{array}$ & $\begin{array}{l}\text { Antiarrhythmics } \\
\text { for maintaining } \\
\text { sinus rhythm } \\
\text { after } \\
\text { cardioversion of } \\
\text { atrial fibrillation }\end{array}$ & $\begin{array}{l}\text { To determine in } \\
\text { patients who } \\
\text { have recovered } \\
\text { sinus rhythm after } \\
\text { having AF, the } \\
\text { effects of long- } \\
\text { term treatment } \\
\text { with } \\
\text { antiarrhythmic } \\
\text { drugs on death, } \\
\text { stroke, embolism, } \\
\text { drug adverse } \\
\text { effects and AF } \\
\text { recurrence. }\end{array}$ & $\begin{array}{l}\text { RCTs comparing } \\
\text { any } \\
\text { antiarrhythmic } \\
\text { drug with a } \\
\text { control in adults } \\
\text { who had AF and } \\
\text { in whom sinus } \\
\text { rhythm was } \\
\text { restored. }\end{array}$ & 59 & 21,305 & $\begin{array}{l}\text { Mortality, Embolic } \\
\text { complications, } \\
\text { and adverse } \\
\text { events. }\end{array}$ & $\begin{array}{l}\text { Adults (> } 16 \\
\text { years) who had } \\
\text { AF of any type } \\
\text { and duration and } \\
\text { in whom sinus } \\
\text { rhythm had been } \\
\text { restored, } \\
\text { spontaneously or } \\
\text { by any } \\
\text { therapeutic } \\
\text { intervention. }\end{array}$ & $\begin{array}{l}\text { Oral long-term } \\
\text { treatment with } \\
\text { any available } \\
\text { antiarrhythmic } \\
\text { drug, at an } \\
\text { appropriate } \\
\text { dosing regime, } \\
\text { aimed at } \\
\text { preventing new } \\
\text { episodes of AF. }\end{array}$ \\
\hline $\begin{array}{l}\text { Salazar et al. } \\
{[31]}\end{array}$ & $\begin{array}{l}\text { Direct thrombin } \\
\text { inhibitors versus } \\
\text { vitamin } \mathrm{K} \\
\text { antagonists for } \\
\text { preventing } \\
\text { cerebral or } \\
\text { systemic embolism } \\
\text { in people with } \\
\text { non-valvular atrial } \\
\text { fibrillation }\end{array}$ & $\begin{array}{l}\text { To assess } \\
\text { comparative } \\
\text { safety and } \\
\text { efficacy of long- } \\
\text { term } \\
\text { anticoagulation } \\
\text { using DTIs versus } \\
\text { VKAs on vascular } \\
\text { deaths and } \\
\text { ischaemic events } \\
\text { in people with } \\
\text { non-valvular AF. }\end{array}$ & $\begin{array}{l}\text { RCTs comparing } \\
\text { DTIs versus VKAs } \\
\text { for prevention of } \\
\text { stroke and } \\
\text { systemic } \\
\text { embolism in } \\
\text { people with non- } \\
\text { valvular AF. }\end{array}$ & 8 & 27,557 & $\begin{array}{l}\text { Vascular death + } \\
\text { ischemic events, } \\
\text { major bleeding. } \\
\text { Composite } \\
\text { outcome of } \\
\text { vascular deaths } \\
\text { and ischaemic } \\
\text { events. } \\
\text { Composite } \\
\text { outcome of fatal } \\
\text { or non-fatal } \\
\text { major bleeding events. }\end{array}$ & $\begin{array}{l}\text { People with non- } \\
\text { valvular AF and } \\
\text { one or more risk } \\
\text { factors for stroke. }\end{array}$ & $\begin{array}{l}\text { DTls at standard } \\
\text { doses compared } \\
\text { with VKAs } \\
\text { (adjusted-dose } \\
\text { warfarin) for an } \\
\text { INR between } 2 \\
\text { and } 3 \text {. }\end{array}$ \\
\hline $\begin{array}{l}\text { Nyong et al. } \\
{[32]}\end{array}$ & $\begin{array}{l}\text { Efficacy and } \\
\text { safety of ablation } \\
\text { for people with } \\
\text { non-paroxysmal } \\
\text { atrial fibrillation }\end{array}$ & $\begin{array}{l}\text { To determine the } \\
\text { efficacy and } \\
\text { safety of ablation } \\
\text { (catheter and } \\
\text { surgical) in } \\
\text { people with } \\
\text { non-paroxysmal } \\
\text { AF compared to } \\
\text { antiarrhythmic } \\
\text { drugs. }\end{array}$ & $\begin{array}{l}\text { RCTs evaluating } \\
\text { the effect of } \\
\text { radiofrequency } \\
\text { catheter ablation } \\
\text { or surgical ablation } \\
\text { compared with } \\
\text { antiarrhythmic } \\
\text { drugs. }\end{array}$ & 3 & 261 & $\begin{array}{l}\text { Freedom from } \\
\text { atrial arrhythmias, } \\
\text { or recurrence of } \\
\text { any atrial } \\
\text { arrhythmias. }\end{array}$ & $\begin{array}{l}\text { Adult patients } \\
\text { with persistent or } \\
\text { long-standing } \\
\text { persistent AF. }\end{array}$ & $\begin{array}{l}\text { Radiofrequency } \\
\text { catheter ablation } \\
\text { technique. }\end{array}$ \\
\hline $\begin{array}{l}\text { Risom et al. } \\
\text { [34] }\end{array}$ & $\begin{array}{l}\text { Exercise-based } \\
\text { cardiac } \\
\text { rehabilitation for } \\
\text { adults with atrial } \\
\text { fibrillation }\end{array}$ & $\begin{array}{l}\text { To assess benefits } \\
\text { and harms of } \\
\text { exercise-based } \\
\text { rehabilitation } \\
\text { programs, alone } \\
\text { or with another } \\
\text { intervention, } \\
\text { compared with } \\
\text { no exercise } \\
\text { training in adults } \\
\text { who currently } \\
\text { have AF, or have } \\
\text { been treated for AF. }\end{array}$ & $\begin{array}{l}\text { RCT that } \\
\text { investigated } \\
\text { exercise-based } \\
\text { interventions } \\
\text { compared with } \\
\text { any type of no- } \\
\text { exercise control. }\end{array}$ & 6 & 421 & $\begin{array}{l}\text { Mortality, serious } \\
\text { adverse events, } \\
\text { health-related } \\
\text { quality of life. }\end{array}$ & $\begin{array}{l}\text { Adult patients } \\
\text { (18 years old or } \\
\text { older) with AF, or } \\
\text { who have been } \\
\text { treated for AF. }\end{array}$ & $\begin{array}{l}\text { Rehabilitation } \\
\text { program with } \\
\text { exercise training } \\
\text { included. } \\
\text { Exercise-based } \\
\text { interventions } \\
\text { were defined as: } \\
\text { any rehabilitation } \\
\text { program in an } \\
\text { inpatient, } \\
\text { outpatient, or } \\
\text { community- or } \\
\text { homebased } \\
\text { setting. }\end{array}$ \\
\hline
\end{tabular}


(Continued)

\begin{tabular}{|c|c|c|c|c|c|c|c|c|}
\hline $\begin{array}{l}\text { Author } \\
\text { (year) }\end{array}$ & Title & Objectives & Studies included & $\begin{array}{l}\text { Trials } \\
(n)\end{array}$ & $\begin{array}{l}\text { Patients } \\
\text { (n) }\end{array}$ & Primary outcomes & $\begin{array}{l}\text { Types of } \\
\text { participants }\end{array}$ & $\begin{array}{l}\text { Types of } \\
\text { interventions }\end{array}$ \\
\hline $\begin{array}{l}\text { Bruins and } \\
\text { Berge [35] }\end{array}$ & $\begin{array}{l}\text { Factor Xa } \\
\text { inhibitors versus } \\
\text { vitamin } \mathrm{K} \\
\text { antagonists for } \\
\text { preventing } \\
\text { cerebral or } \\
\text { systemic } \\
\text { embolism in } \\
\text { patients with AF. }\end{array}$ & $\begin{array}{l}\text { To assess the } \\
\text { effectiveness and } \\
\text { safety of } \\
\text { treatment with } \\
\text { factor Xa } \\
\text { inhibitors versus } \\
\text { VKAs for } \\
\text { preventing } \\
\text { cerebral or } \\
\text { systemic embolic } \\
\text { events in people } \\
\text { with AF. }\end{array}$ & $\begin{array}{l}\text { RCTs that directly } \\
\text { compared effects } \\
\text { of long-term } \\
\text { treatment with } \\
\text { Factor Xa } \\
\text { inhibitors vs. VKAs } \\
\text { for preventing } \\
\text { cerebral and } \\
\text { systemic } \\
\text { embolism in AF } \\
\text { patients. }\end{array}$ & 13 & 67,688 & $\begin{array}{l}\text { The composite } \\
\text { endpoint of all } \\
\text { strokes (both } \\
\text { ischaemic and } \\
\text { hemorrhagic) and } \\
\text { other systemic } \\
\text { embolic events. }\end{array}$ & $\begin{array}{l}\text { People with AF } \\
\text { who were } \\
\text { eligible for } \\
\text { treatment with } \\
\text { anticoagulants. }\end{array}$ & $\begin{array}{l}\text { Treatment with } \\
\text { an oral or } \\
\text { parenteral factor } \\
\text { Xa inhibitor } \\
\text { versus oral } \\
\text { vitamin K } \\
\text { antagonists } \\
\text { (warfarin and } \\
\text { congeners) with } \\
\text { the intensity } \\
\text { monitored using } \\
\text { INR. }\end{array}$ \\
\hline $\begin{array}{l}\text { Moran et al. } \\
\text { [39] }\end{array}$ & $\begin{array}{l}\text { Systematic } \\
\text { screening for the } \\
\text { detection of atrial } \\
\text { fibrillation }\end{array}$ & $\begin{array}{l}\text { The primary } \\
\text { objective of the } \\
\text { review was to } \\
\text { investigate } \\
\text { whether evidence } \\
\text { shows differences } \\
\text { between } \\
\text { systematic } \\
\text { screening and } \\
\text { routine practice in } \\
\text { the detection of } \\
\text { new cases of AF }\end{array}$ & $\begin{array}{l}\text { RCTs and cluster- } \\
\text { RCTs comparing } \\
\text { systematic } \\
\text { screening vs. } \\
\text { routine practice. }\end{array}$ & 1 & 9137 & $\begin{array}{l}\text { Primary outcome } \\
\text { under } \\
\text { investigation was } \\
\text { the difference in } \\
\text { the detection of } \\
\text { new cases of AF } \\
\text { associated with } \\
\text { systematic } \\
\text { screening } \\
\text { compared with } \\
\text { routine practice. }\end{array}$ & $\begin{array}{l}\text { Men and women } \\
\text { over the age of } \\
40 \text { years. }\end{array}$ & $\begin{array}{l}\text { This was a } \\
\text { diagnostic } \\
\text { screening study } \\
\text { so no } \\
\text { intervention per } \\
\text { se. Studies eligible } \\
\text { for inclusion } \\
\text { compared } \\
\text { population-based, } \\
\text { targeted or } \\
\text { opportunistic } \\
\text { screening } \\
\text { program versus } \\
\text { no screening. }\end{array}$ \\
\hline $\begin{array}{l}\text { Clarkesmith } \\
\text { et al. [36] }\end{array}$ & $\begin{array}{l}\text { Educational and } \\
\text { behavioural } \\
\text { interventions for } \\
\text { anticoagulant } \\
\text { therapy in } \\
\text { patients with } \\
\text { atrial fibrillation }\end{array}$ & $\begin{array}{l}\text { To evaluate the } \\
\text { effects of } \\
\text { educational and } \\
\text { behavioural } \\
\text { interventions for } \\
\text { OAC on TTR in AF } \\
\text { patients. }\end{array}$ & $\begin{array}{l}\text { RCTs evaluating } \\
\text { the effect of any } \\
\text { educational and } \\
\text { behavioral } \\
\text { intervention } \\
\text { compared with } \\
\text { usual care, no } \\
\text { intervention, or } \\
\text { intervention in } \\
\text { combination with } \\
\text { other self- } \\
\text { management } \\
\text { techniques. }\end{array}$ & 11 & 2246 & $\begin{array}{l}\text { Primary outcome } \\
\text { measure was TTR. }\end{array}$ & $\begin{array}{l}\text { Adults diagnosed } \\
\text { with } \mathrm{AF}\end{array}$ & $\begin{array}{l}\text { All types of } \\
\text { educational and } \\
\text { behavioural } \\
\text { interventions. }\end{array}$ \\
\hline $\begin{array}{l}\text { Chen et al. } \\
\text { [37] }\end{array}$ & $\begin{array}{l}\text { Catheter ablation } \\
\text { for paroxysmal } \\
\text { and persistent } \\
\text { atrial fibrillation }\end{array}$ & $\begin{array}{l}\text { The primary } \\
\text { objective was to } \\
\text { assess the } \\
\text { beneficial and } \\
\text { harmful effects of } \\
\text { catheter ablation } \\
\text { in comparison } \\
\text { with medical } \\
\text { treatment in } \\
\text { patients with } \\
\text { paroxysmal and } \\
\text { persistent AF. }\end{array}$ & $\begin{array}{l}\text { RCTs in people } \\
\text { with paroxysmal } \\
\text { and persistent AF } \\
\text { treated by any } \\
\text { type of ablation } \\
\text { method. }\end{array}$ & 7 & 3560 & $\begin{array}{l}\text { Recurrence of AF, } \\
\text { fatal and non-fatal } \\
\text { embolic } \\
\text { complications. All- } \\
\text { cause mortality, } \\
\text { death due to } \\
\text { thrombo-embolic } \\
\text { events. }\end{array}$ & $\begin{array}{l}\text { Patients with } \\
\text { paroxysmal and } \\
\text { persistent AF. }\end{array}$ & $\begin{array}{l}\text { Any type of } \\
\text { catheter ablation, } \\
\text { including } \\
\text { pulmonary vein } \\
\text { electrical isolation, } \\
\text { superior vena } \\
\text { cava isolation, left } \\
\text { atrium posterior } \\
\text { wall ablation and } \\
\text { others. }\end{array}$ \\
\hline $\begin{array}{l}\text { Mead et al.* } \\
{[40]}\end{array}$ & $\begin{array}{l}\text { Electrical } \\
\text { cardioversion for } \\
\text { atrial fibrillation } \\
\text { and flutter }\end{array}$ & $\begin{array}{l}\text { To assess effects } \\
\text { of cardioversion } \\
\text { of AF/ flutter on } \\
\text { risk of } \\
\text { thromboembolic } \\
\text { events, strokes } \\
\text { and mortality, the } \\
\text { rate of cognitive } \\
\text { decline, quality of } \\
\text { life, the use of } \\
\text { anticoagulants } \\
\text { and risk of re- } \\
\text { hospitalisation. }\end{array}$ & $\begin{array}{l}\text { RCTs of electrical } \\
\text { cardioversion plus } \\
\text { 'usual care' vs. } \\
\text { 'usual care' only. }\end{array}$ & 3 & 927 & $\begin{array}{l}\text { Primary outcome: } \\
\text { risk of stroke, } \\
\text { peripheral embolism, } \\
\text { and death. }\end{array}$ & $\begin{array}{l}\text { Adults with } \\
\text { paroxysmal, } \\
\text { sustained or } \\
\text { permanent AF or } \\
\text { atrial flutter. }\end{array}$ & $\begin{array}{l}\text { Electrical } \\
\text { cardioversion } \\
\text { used as a first } \\
\text { intervention plus } \\
\text { 'usual care' versus } \\
\text { 'usual care' only. } \\
\text { 'Usual care' } \\
\text { included drugs } \\
\text { for 'rate control', } \\
\text { anticoagulants or } \\
\text { antiplatelet drugs. }\end{array}$ \\
\hline
\end{tabular}


(Continued)

\begin{tabular}{|c|c|c|c|c|c|c|c|c|}
\hline $\begin{array}{l}\text { Author } \\
\text { (year) }\end{array}$ & Title & Objectives & Studies included & $\begin{array}{l}\text { Trials } \\
(n)\end{array}$ & $\begin{array}{l}\text { Patients } \\
(n)\end{array}$ & Primary outcomes & $\begin{array}{l}\text { Types of } \\
\text { participants }\end{array}$ & $\begin{array}{l}\text { Types of } \\
\text { interventions }\end{array}$ \\
\hline $\begin{array}{l}\text { Heneghan } \\
\text { et al. [38] }\end{array}$ & $\begin{array}{l}\text { Self-monitoring } \\
\text { and self- } \\
\text { management of } \\
\text { oral } \\
\text { anticoagulation }\end{array}$ & $\begin{array}{l}\text { To evaluate } \\
\text { effects on } \\
\text { thrombotic } \\
\text { events, major } \\
\text { hemorrhages, and } \\
\text { all-cause mortality } \\
\text { of self-monitoring } \\
\text { or self- } \\
\text { management of } \\
\text { oral } \\
\text { anticoagulation } \\
\text { compared with } \\
\text { standard } \\
\text { monitoring. }\end{array}$ & $\begin{array}{l}\text { RCTs assessing } \\
\text { the therapeutic } \\
\text { effectiveness and } \\
\text { safety of self- } \\
\text { monitoring or } \\
\text { self-management } \\
\text { of oral } \\
\text { anticoagulation } \\
\text { therapy. }\end{array}$ & 28 & 8950 & $\begin{array}{l}\text { Primary outcomes } \\
\text { were } \\
\text { thromboembolic } \\
\text { events, all-cause } \\
\text { mortality, major } \\
\text { haemorrhage, } \\
\text { TR. }\end{array}$ & $\begin{array}{l}\text { All patients on } \\
\text { long-term OAC } \\
\text { (treatment } \\
\text { duration longer } \\
\text { than two } \\
\text { months), } \\
\text { irrespective of } \\
\text { the indication for } \\
\text { treatment. }\end{array}$ & $\begin{array}{l}\text { Self-monitoring or } \\
\text { self-management } \\
\text { of oral } \\
\text { anticoagulation }\end{array}$ \\
\hline
\end{tabular}

AF Atrial Fibrillation, CKD Chronic Kidney Disease, $\mathrm{CrCl}$ Creatinine Clearance, DOAC Direct Thrombin Inhibitor, DTI Direct Thrombin Inhibitor, eGFR Estimated Glomerular Filtration Rate, INR International Normalized Ratio, OAC Oral Anticoagulant, RCT Randomized Controlled Trials, TIA Transient Ischemic Attack, TTR Time in Therapeutic Range

*This review was subsequently withdrawn.

\section{Supplementary information}

Supplementary information accompanies this paper at https://doi.org/10. 1186/s13643-019-1152-z.

Additional file 1. Proposed items to be used for reporting methodology research, adapted from the PRISMA Checklist (http:// prismastatement.org/PRISMAStatement/Checklist.aspx)

Additional file 2. AMSTAR-2 Risk of Bias for Included Systematic Reviews

\section{Abbreviations}

AF: Atrial fibrillation; AMSTAR: A MeaSurement Tool to Assess systematic Reviews; Cl: Confidence interval; I2: I-squared; IQR: Interquartile range; NOAC: Non-vitamin K anticoagulant; OAC: Oral anticoagulant; OR: Odds ratio; PROSPERO: International Prospective Register of Systematic Reviews; SR: Systematic review; TIA: Transient ischemic attack; VKA: Vitamin K antagonist

\section{Data Sharing}

The datasets used and/or analyzed during the current study are available from the corresponding author on reasonable request.

\section{Authors' contributions}

MP was responsible for the design of the work, acquisition of data, analysis, interpretation of data, and for writing the manuscript. AMA was responsible for acquisition of data, interpretation of data, and review of the manuscript. $\mathrm{RN}$ was responsible for interpretation of data and writing the manuscript. NS was responsible for interpretation of data and critical review of the manuscript. LM was responsible for conception of the work, interpretation of the data, manuscript drafting, and review. All authors read and approved the final manuscript.

\section{Funding}

This research did not receive any specific grant from funding agencies in the public, commercial, or not-for-profit sectors.

\section{Ethics approval and consent to participate}

Ethics approval was not required for this study as only aggregate published data were used.

\section{Consent for publication}

Not applicable.

\section{Competing interests}

MP is an employee of Boehringer Ingelheim Ltd. The other authors declare that they have no competing interests.

\section{Author details}

${ }^{1}$ Department of Health Research Methods, Evidence, and Impact, McMaster University, Hamilton, Ontario L8S 4K1, Canada. ${ }^{2}$ Medical Department, Boehringer Ingelheim Ltd., Burlington, Ontario, Canada. ${ }^{3}$ Pediatric Endocrinology Department, King Abdullah bin Abdulaziz University hospital, Princess Noura University, Riyadh, Saudi Arabia. ${ }^{4}$ Biostatistics Unit, Father Sean O'Sullivan Research Centre, St Joseph's Healthcare Hamilton, Hamilton, Ontario, Canada. ${ }^{5}$ Centre for the Development of Best Practices in Health, Yaoundé, Cameroon.

Received: 20 May 2019 Accepted: 10 September 2019

Published online: 25 October 2019

\section{References}

1. Sackett DL, Rosenberg WM, Gray JA, Haynes RB, Richardson WS. Evidence based medicine: what it is and what it isn't. BMJ. 1996;312(7023):71-2.

2. Deeks JJ HJ, Altman DJ (editors). Chapter 9: Analysing data and undertaking meta-analyses. Cochrane Handbook for Systematic Reviews of Interventions Version 5.1.0 [updated March 2011]. The Cochrane Collaboration, 2011. Available from www.handbook.cochrane.org. 2011.

3. Gagnier JJ, Morgenstern H, Altman DG, Berlin J, Chang S, McCulloch P, et al. Consensus-based recommendations for investigating clinical heterogeneity in systematic reviews. BMC Med Res Methodol. 2013;13:106.

4. Gagnier JJ, Moher D, Boon H, Beyene J, Bombardier C. Investigating clinical heterogeneity in systematic reviews: a methodologic review of guidance in the literature. BMC Med Res Methodol. 2012;12:111.

5. Higgins JP, Thompson SG. Quantifying heterogeneity in a meta-analysis. Stat Med. 2002;21(11):1539-58.

6. Guyatt GH, Oxman AD, Kunz R, Woodcock J, Brozek J, Helfand M, et al. GRADE guidelines: 7. Rating the quality of evidence--inconsistency. J Clin Epidemiol. 2011;64(12):1294-302.

7. Thompson SG, Higgins JPT. How should meta-regression analyses be undertaken and interpreted? Stat Med. 2002;21(11):1559-73.

8. Higgins J, Thompson S, Deeks J, Altman D. Statistical heterogeneity in systematic reviews of clinical trials: a critical appraisal of guidelines and practice. J Health Serv Res Policy. 2002;7(1):51-61.

9. Guyatt $\mathrm{GH}$, Oxman AD, Vist GE, Kunz R, Falck-Ytter $Y$, Alonso-Coello $P$, et al. GRADE: an emerging consensus on rating quality of evidence and strength of recommendations. BMJ. 2008;336(7650):924-6.

10. Sun X, loannidis JP, Agoritsas T, Alba AC, Guyatt G. How to use a subgroup analysis: users' guide to the medical literature. JAMA 2014;311(4):405-411.

11. Page MJ, Altman DG, McKenzie JE, Shamseer L, Ahmadzai N, Wolfe D, et al. Flaws in the application and interpretation of statistical analyses in systematic reviews of therapeutic interventions were common: a crosssectional analysis. J Clini Epidemiol. 2018;95:7-18.

12. Donegan S, Williams L, Dias S, Tudur-Smith C, Welton N. Exploring treatment by covariate interactions using subgroup analysis and metaregression in cochrane reviews: a review of recent practice. PLOS ONE. 2015. 10(6):e0128804 
13. Riley RD, Gates S, Neilson J, Alfirevic Z. Statistical methods can be improved within Cochrane pregnancy and childbirth reviews. J Clin Epidemiol. 2011; 64(6):608-18.

14. Nieuwlaat R, Capucci A, Camm AJ, Olsson SB, Andresen D, Davies DW, et al. Atrial fibrillation management: a prospective survey in ESC member countries: the Euro Heart Survey on Atrial Fibrillation. Eur Heart J. 2005; 26(22):2422-34

15. Hart RG, Pearce LA, McBride R, Rothbart RM, Asinger RW. Factors associated with ischemic stroke during aspirin therapy in atrial fibrillation: analysis of 2012 participants in the SPAF I-III clinical trials. The Stroke Prevention in Atrial Fibrillation (SPAF) Investigators. Stroke. 1999;30(6):1223-9.

16. Lip GY, Nieuwlaat R, Pisters R, Lane DA, Crijns HJ. Refining clinical risk stratification for predicting stroke and thromboembolism in atrial fibrillation using a novel risk factor-based approach: the Euro Heart Survey on Atrial Fibrillation. Chest. 2010;137(2):263-72.

17. Wolf PA, Abbott RD, Kannel WB. Atrial fibrillation as an independent risk factor for stroke: the Framingham Study. Stroke. 1991;22(8):983-8.

18. Marinigh R, Lip GY, Fiotti N, Giansante C, Lane DA. Age as a risk factor for stroke in atrial fibrillation patients: implications for thromboprophylaxis. J Am Coll Cardiol. 2010;56(11):827-37.

19. Agarwal M, Apostolakis S, Lane DA, Lip GY. The impact of heart failure and left ventricular dysfunction in predicting stroke, thromboembolism, and mortality in atrial fibrillation patients: a systematic review. Clin Ther. 2014; 36(9):1135-44

20. Lip GY, Banerjee A, Lagrenade I, Lane DA, Taillandier S, Fauchier L. Assessing the risk of bleeding in patients with atrial fibrillation: the Loire Valley Atrial Fibrillation project. Circ Arrhythm Electrophysiol. 2012;5(5):941-8.

21. Shea BJ, Reeves BC, Wells G, Thuku M, Hamel C, Moran J, et al. AMSTAR 2: a critical appraisal tool for systematic reviews that include randomised or nonrandomised studies of healthcare interventions, or both. BMJ. 2017;358:j4008.

22. Murad MH, Wang Z. Guidelines for reporting meta-epidemiological methodology research. Evid Based Med. 2017;22(4):139-42.

23. Booth A, Clarke M, Dooley G, Ghersi D, Moher D, Petticrew M, et al. PROSPERO at one year: an evaluation of its utility. Syst Rev. 2013;2:4.

24. Aguilar MI, Hart R. Oral anticoagulants for preventing stroke in patients with non-valvular atrial fibrillation and no previous history of stroke or transient ischemic attacks. Cochrane Database Syst Rev. 2005;3.

25. Aguilar Ml, Hart R. Antiplatelet therapy for preventing stroke in patients with non-valvular atrial fibrillation and no previous history of stroke or transient ischemic attacks. Cochrane Database Syst Rev. 2005;4.

26. Aguilar MI, Hart R, Pearce LA. Oral anticoagulants versus antiplatelet therapy for preventing stroke in patients with non-valvular atrial fibrillation and no history of stroke or transient ischemic attacks. Cochrane Database Syst Rev. 2007;3.

27. Saxena R, Koudstaal PJ. Anticoagulants for preventing stroke in patients with nonrheumatic atrial fibrillation and a history of stroke or transient ischaemic attack. Cochrane Database Syst Rev. 2004;2.

28. Saxena R, Koudstaal PJ. Anticoagulants versus antiplatelet therapy for preventing stroke in patients with nonrheumatic atrial fibrillation and a history of stroke or transient ischemic attack. Cochrane Database Syst Rev. 2004;4.

29. Kimachi M, Furukawa TA, Kimachi K, Goto Y, Fukuma S, Fukuhara S. Direct oral anticoagulants versus warfarin for preventing stroke and systemic embolic events among atrial fibrillation patients with chronic kidney disease. Cochrane Database Syst Rev. 2017;(11).

30. Lafuente-Lafuente C, Valembois L, Bergmann JF, Belmin J. Antiarrhythmics for maintaining sinus rhythm after cardioversion of atrial fibrillation. Cochrane Database Syst Rev. 2015;(3)

31. Salazar CA, del Aguila D, Cordova EG. Direct thrombin inhibitors versus vitamin K antagonists for preventing cerebral or systemic embolism in people with non-valvular atrial fibrillation. Cochrane Database Syst Rev 2014(3).

32. Nyong J, Amit G, Adler AJ, Owolabi OO, Perel P, Prieto-Merino D, et al. Efficacy and safety of ablation for people with non-paroxysmal atrial fibrillation. Cochrane Database Syst Rev. 2016;(11).

33. Huffman MD, Karmali KN, Berendsen MA, Andrei AC, Kruse J, McCarthy PM et al. Concomitant atrial fibrillation surgery for people undergoing cardiac surgery. Cochrane Database Syst Rev. 2016;(8)

34. Risom SS, Zwisler AD, Johansen PP, Sibilitz KL, Lindschou J, Gluud C, et al. Exercise-based cardiac rehabilitation for adults with atrial fibrillation. Cochrane Database Syst Rev. 2017;(2)
35. Bruins Slot $\mathrm{KMH}$, Berge E. Factor Xa inhibitors versus vitamin $\mathrm{K}$ antagonists for preventing cerebral or systemic embolism in patients with atrial fibrillation. Cochrane Database Syst Rev. 2018;(3).

36. Clarkesmith DE, Pattison HM, Khaing PH, Lane DA. Educational and behavioural interventions for anticoagulant therapy in patients with atrial fibrillation. Cochrane Database Syst Rev. 2017;(4).

37. Chen HS, Wen JM, Wu SN, Liu JP. Catheter ablation for paroxysmal and persistent atrial fibrillation. Cochrane Database Syst Rev. $(2012,4)$.

38. Heneghan CJ, Garcia-Alamino JM, Spencer EA, Ward AM, Perera R, Bankhead $C$, et al. Self-monitoring and self-management of oral anticoagulation. Cochrane Database Syst Rev. 2016;(7).

39. Moran PS, Teljeur C, Ryan M, Smith SM. Systematic screening for the detection of atrial fibrillation. Cochrane Database Syst Rev. 2016;(6).

40. Mead GE, Elder A, Flapan AD, Cordina J. Electrical cardioversion for atrial fibrillation and flutter. Cochrane Database Syst Rev. 2017;(11)

41. Bahiru E, de Cates AN, Farr MRB, Jarvis MC, Palla M, Rees K, et al. Fixed-dose combination therapy for the prevention of atherosclerotic cardiovascular diseases. Cochrane Database Syst Rev. 2017;(3)

42. Gage BF, Waterman AD, Shannon W, Boechler M, Rich MW, Radford MJ. Validation of clinical classification schemes for predicting stroke: results from the National Registry of Atrial Fibrillation. JAMA. 2001;285(22):2864-70.

43. Higgins JP, Altman DG, Gotzsche PC, Juni P, Moher D, Oxman AD, et al. The Cochrane Collaboration's tool for assessing risk of bias in randomised trials. BMJ. 343:d5928.

44. Mbuagbaw L, Morgano GP, Lawson DO, Nyambi A, Youssef M, Olaiya O, et al. Subgroup analyses are seldom possible and subgroup effects are rare in Cochrane HIV systematic reviews. J Clin Epidemiol. 2018;104:143-4.

45. Oxman AD. Subgroup analyses: the devil is in the interpretation. BMJ (Online) 2012;344 (7852) (no pagination) (e2022).

46. Groenwold RHH, Donders ART, Van Der Heijden GJMG, Hoes AW, Rovers MM. Confounding of subgroup analyses in randomized data. Arch Intern Med. 2009;169(16):1532-4.

47. Higgins JPT SJ, Savović J, Page MJ, Hróbjartsson A, Boutron I RB, Eldridge S. A revised tool for assessing risk of bias in randomized trials In: Chandler J, McKenzie J, Boutron I, Welch V (editors). Cochrane Database Syst Rev 2016, Issue 10 (Suppl1) 2016

48. Page MJ, Shamseer L, Altman DG, Tetzlaff J, Sampson M, Tricco AC, et al. Epidemiology and reporting characteristics of systematic reviews of biomedical research: a cross-sectional study. PLoS Med. 2016;13(5):e1002028.

\section{Publisher's Note}

Springer Nature remains neutral with regard to jurisdictional claims in published maps and institutional affiliations.

Ready to submit your research? Choose BMC and benefit from

- fast, convenient online submission

- thorough peer review by experienced researchers in your field

- rapid publication on acceptance

- support for research data, including large and complex data types

- gold Open Access which fosters wider collaboration and increased citations

- maximum visibility for your research: over $100 \mathrm{M}$ website views per year

At $\mathrm{BMC}$, research is always in progress.

Learn more biomedcentral.com/submission 